\title{
Mastery of Understanding the Meaning of Parables by Orang Asli of the Temiar Tribe Students through Malay Proverb
}

\author{
Tunku Aidayuhanna Raja Mafuzin, Wan Muna Ruzanna Wan Mohammad* \\ Centre Department of Innovation in Teaching \& Learning, Faculty of Education, Universiti Kebangsaan Malaysia, 43600, Bangi \\ Selangor, Malaysia
}

Received July 30, 2020; Revised October 7, 2020; Accepted October 30, 2020

\section{Cite This Paper in the following Citation Styles}

(a): [1] Tunku Aidayuhanna Raja Mafuzin, Wan Muna Ruzanna Wan Mohammad, "Mastery of Understanding the Meaning of Parables by Orang Asli of the Temiar Tribe Students through Malay Proverb," Universal Journal of Educational Research, Vol. 8, No. 11A, pp. 103 - 109, 2020. DOI: 10.13189/ujer.2020.082113.

(b): Tunku Aidayuhanna Raja Mafuzin, Wan Muna Ruzanna Wan Mohammad (2020). Mastery of Understanding the Meaning of Parables by Orang Asli of the Temiar Tribe Students through Malay Proverb. Universal Journal of Educational Research, 8(11A), 103 - 109. DOI: 10.13189/ujer.2020.082113.

Copyright $\odot 2020$ by authors, all rights reserved. Authors agree that this article remains permanently open access under the terms of the Creative Commons Attribution License 4.0 International License

\begin{abstract}
This study aims to explore comprehension mastery for the meaning of parables by the Orang Asli of the Temiar Tribe. The design of this study is a case study involving a total of five Form Two Orang Asli students of the Temiar Tribe as study participants. Form two students were chosen because they have already been exposed to parables at the secondary school level, from when they were in form one. Study data were analysed qualitatively using the adaptation and modification of Semiotic Theory and Social Constructivism Theory. The study participants answered a total of three parable questions in a set of Cermin Minda. Parables are one of the types of proverbs which are listed in the Curriculum and Assessment Standard Document for the Malay Language, for Form Two students. The results of the study found all of the study participants failed to give the correct answer when stating parables and their meanings based on the matching visual objects given in the question. Based on the answer given, the study participants can state the name of the visual object in the matching visual object, but unfortunately, they were not able to state the correct parable. This is because the answers given by the study participants do not reflect the actual parable itself. Only one study participant was able to express the parable correctly. However, all other study participants failed to provide the correct answer for the meaning of each parable. Based on the findings of this study, Orang Asli of the Temiar Tribe students are still weak in stating parable and
\end{abstract}

their meanings. Teachers need to give the special and continuous attention.

Keywords Parables, Temiar Tribe Students, Semiotic Theory, Social Constructivism Theory

\section{Introduction}

\subsection{Malay Language in Education}

The Malay language is seen as Malaysia's unifying language and is recognized as the national language of Malaysia. This is clearly stipulated in Perkara 152, where the national language is Malay. [1] clarifies that the role of educational institutions in Malaysia is to realize the vision of the country in achieving the status of a developed country. Thus, Malaysia has chosen the Malay language as the main medium in schools and all other educational institutions. This matter is supported by [2], where the Malay language has been recognized as the national language for its role as a unifying language.

In education, The Curriculum and Assessment Standard Document Malay Language is the official reference of the Malay language teachers. The Curriculum and Assessment Standard Document supports the role of the Malay 
language as the national language, official language, the language of unity, language of knowledge and language of instruction in schools. The proverbs contained in The Curriculum and Assessment Standard Document, namely idioms, parables, sayings, proverbs, numbers and words of wisdom belong to the figurative language, and they emphasise on philosophy, personality and noble values based on the multiracial Malaysian society. In this context, Malaysians or even non-native speakers of Bahasa Malaysia must learn all the items stipulated and contained in the Curriculum and Assessment Standard Document for the Malay Language, and use the Malay language as the main medium during the teaching and learning process. So, what is the level of mastery of understanding the meaning of parables of the Orang Asli students of the Temiar Tribe?

\subsection{Orang Asli of the Temiar Tribe}

Orang Asli of the Temiar Tribe inhabiting the northern The Orang Asli of the Temiar Tribe inhabit the northern part of Perak and the southern part of Kelantan. Based on [3], this tribe represents about 16 percent of the population of Orang Asli in Peninsular Malaysia. According to [4], the Orang Asli status is given when the mother or father, or both of them are indigenous people, speak Aslian languages, and their ways of life and beliefs are mainly rooted in indigenous customs and beliefs. The Orang Asli or indigenous people are the aborigines of Malaysia. The Orang Asli in Peninsular Malaysia consist of three main tribal groups which are the Orang Asli Senoi group, Orang Asli Proto Malay group and Orang Asli Negrito group, [5]. Each group consists of six tribes, where the Orang Asli Senoi group is further separated into the Semai, Temiar, Semoq Beri, Che Wong, Jahut and Mah Meri tribes. Meanwhile, the Orang Asli Proto Malay group is divided into the Temuan, Semelai, Orang Laut (Kuala), Orang Kanaq, Orang Seletar and Jakun Tribe. The Orang Asli Negrito group consists of the Mendriq, Kensiu, Bateq, Kintak, Jahai and Lanoh Tribe (Table 1). [6] states that the division of the three major group is based on the justification of views from an ethnological point of view (field method of anthropological study).

Table 1. Information of Orang Asli Tribe in Peninsular Malaysia [5]

\begin{tabular}{|c|c|c|}
\hline $\begin{array}{c}\text { Orang Asli } \\
\text { Senoi Tribe }\end{array}$ & $\begin{array}{c}\text { Orang Asli Melayu } \\
\text { Proto Tribe }\end{array}$ & $\begin{array}{c}\text { Orang Asli } \\
\text { Negrito Tribe }\end{array}$ \\
\hline Semai & Temuan & Mendriq \\
\hline Temiar & Semelai & Kensiu \\
\hline Semoq Beri & Orang Laut (Kuala) & Bateq \\
\hline Che Wong & Orang Kanaq & Kintak \\
\hline Jahut & Orang Seletar & Jahai \\
\hline Mah Meri & Jakun & Lanoh \\
\hline
\end{tabular}

\subsection{Parables in Malay Proverbs}

[7] states that proverbs are a set of short conversations spoken by the community because they contain beautiful words, can be used widely and have a clear purpose, which is, to function as comparisons or examples, with (moral) lessons attached. According to [8], the Malay language is rich in idioms that can be described as the 'pearl' in Malay proverbs because the proverbs themselves have been described as a reflection of the culture and mindset of the Malay community since time immemorial. The origin of proverbs according to [9] is the figurative language, which is divided into two categories involving proverbs (figuratively established in terms of language form, consisting of idioms, parables, sayings, proverbs and words of wisdom) and non-proverbs (figurative which is not a stable form of language, and its meaning consists of personification, hyperbole and metaphor) (Figure 1).

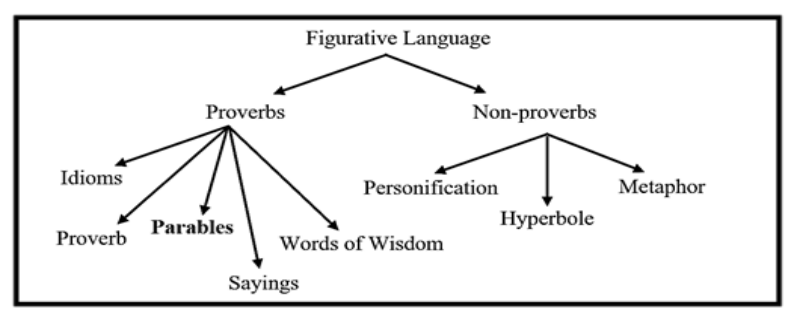

Figure 1. Division of Figurative Language [9]

Parable is a comparison of human behaviour, nature or environment which contains implicit and explicit meaning. Thus, the words of bagai, bak, ibarat, laksana, macam, seperti, and umpama can be used as parables to compare something, [10]. [11] defines that a parable as a figurative language or figurative metaphor that gives meaning in two layers, after likening it to something that is comparable to it. This matter is in line with [12], who states that the parable is a proverb that publishes its meaning through allusions to other things.

\subsection{Malay Language as a Second Language (B2)}

The Mother-tongue (known as mother language) or B1 for the Orang Asli of the Temiar Tribe students is the Temiar language, while the Malay language functions as their secondary language (B2). According to [13], the B2 presents after the speaker has mastered his B1 and this usually takes place through formal learning in school. This matter is supported by [14], that is, after a person has mastered a system, then B2 learning will take place.

So, the Orang Asli of the Temiar Tribe students must master the Malay language as it is used in the teaching and learning process in the classroom. This matter is in line with [15], where the Malay language is the language of communication and language of instruction in schools. During the process of learning and mastering B2, every Orang Asli of the Temiar Tribe student has to go through a complex journey, and this is confirmed by [16] who stated that B2 teaching should be carefully planned, occur naturally as well as emphasize cultural and social contexts 
so that it is spoken and heard frequently.

\section{Theoretical Framework}

The theory that is used in this study is the adapted and modified Semiotic Theory (1915-1980) by [17] and Social Constructivism Theory (1896-1934) by [18] (Figure 2). In the Semiotic Theory (1915-1980), introduced by Roland Barthes, the semiotics itself has two stages, where the first stage has the reality and signs that served to explain the relationship of signified and signifier in reality that produces the denotative meaning (gives meaning explicitly, directly and precisely). The second stage, meanwhile, carries a culture that creates meaning connotatively (gives meaning implicitly, indirectly, uncertainly), [19] and myth (a sign given connotative meaning, develops into denotative meaning to form myths), [17]. After completing these two stages, an understanding of the meaning can be achieved, that is, the new cognitive production. At the same time, the Theory of Social Constructivism which has merged through existing knowledge (cognitive), is in the first stage of the Semiotic Theory. If existing knowledge is put and placed into good use, then, an individual is able to generate the meaning denotatively. Subsequently, the teaching and learning process continues in line with the detection of signified and signifier in Semiotic Theory. Finally, an implicit understanding of the meaning will be gained in the second stage to produce new cognitive.

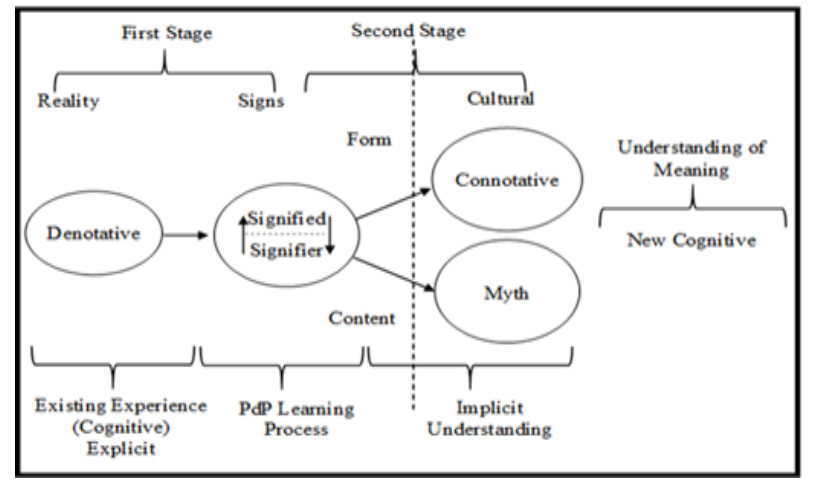

Figure 2. Combination of The Semiotic Theory by Roland Barthes and The Social Constructivism by Lev Vygotsky

\section{Methodology}

The design of this study is a case study because it focused on the mastery of understanding the meaning of parables by Form Two Orang Asli students of the Temiar Tribe. The study was conducted at a regular daily national secondary school in Perak. Participants in this study consisted of five Form Two Orang Asli students of the Temiar Tribe. The participants were labelled as Peserta Kajian 1 (PK 1), Peserta Kajian 2 (PK 2), Peserta Kajian 3
(PK 3), Peserta Kajian 4 (PK 4), and Peserta Kajian 5 (PK 5). The instrument used is only a set of written tests known as the Parable Type Cermin Minda. The instrument has been certified by an expert in the field of language and literature. In this study, the researchers conducted a written test to discover the mastery of understanding the meaning of parables, through Malay proverbs, by students who are the Orang Asli of the Temiar Tribe. The five PKs were asked to answer three parable questions based on the matching visual objects as this method will trigger ideas to the PKs to form correct parables. All the PKs were required to write the parables and state their meaning clearly for each question given.

\section{Findings and Discussion}

Mastery of understanding the meaning of parables through Malay proverbs is important for students because it is listed as one of the 10 common objectives in The Curriculum and Assessment Standard Document for Malay Language for Form Two [20]. Three parables and their meanings in the findings of this study were taken from the Peribahasa Sekolah Menengah book written by [21], published by Dewan Bahasa dan Pustaka.

\section{Parable 1: Bagai tikus membaiki labu}

'Bagai tikus membaiki labu' means someone trying to fix something unknown, only to add more damage to it. The denotative or external meaning of this parable is, when the rat approaches the pumpkin, the rat is not able to repair any damages but only makes the pumpkin as its food because the pumpkin is one of its food sources. This statement refers to [22], where the rats are pests and can cause pumpkins to be in bad and useless conditions. When discussing the parable of 'bagai tikus membaiki labu' in terms of connotative meaning, it clearly shows that an item will become more damaged if it is to be repaired by an unskilled person. The damage may be minimal at first, but when the unskilled person repairs it, the damage will increase and eventually cause the item to be rendered useless. The description given by the ancient Malay community clearly shows the elevation in their level of thought. The events that exist in the natural environment can be meaningfully alluded to universal human life, in addition to its limitless use of time and age.
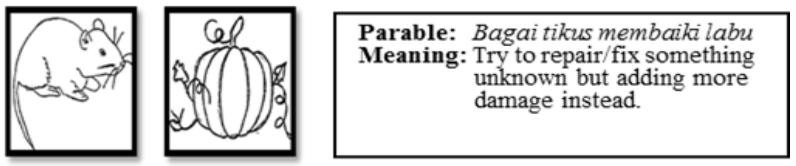

Answered by Study Participants (PK):

PK 1: Parable: Bagai tikus jatuh ke buah labu Meaning: Kepada orang yang suka mencuri.

PK 2: Parable: Seperti tikus jatuh ke labu 
Meaning: Orang yang sudah mengalah.

PK 3: Parable: Bagai tikus perbaiki labu

Meaning: Labu itu sudah rosak tetapi tikus akan perbaikinya.

PK 4: Parable: Bagai tikus dengan buah labu Meaning: Tikus mencari makan dengan mata tajamnya terus nampak buah labu.

PK 5: Parable: Tikus sedang menghidu bau buah labu Meaning: Tikus mahu makan buah labu.

The answer to this second question shows that only one respondent or Peserta Kajian (PK) wrote the parable correctly, namely PK 3. Meanwhile, PK 1, PK 2, PK 4 and PK 5 could not give the correct answer even though they were able to name the matching visual object correctly. This shows that all PKs have the existing knowledge based on their living environment, where farming or cultivation takes place. This is clearly stated based on [23], where the Orang Asli of the Temiar Tribe raise their families by being involved in farming or cultivation, hunting and gathering forest produce. Meanwhile, all PKs cannot give the meaning of the 'bagai tikus membaiki labu' parable correctly as it is connotatively intended. However, based on the answers of all PKs, it is found that the essence of the parable already exists but the means of processing its meaning is not reached yet. Drawing from the adaptation and modification of the Semiotic Theory and Social Constructivism Theory, the participants have existing knowledge and can pass the first stage which is the reality and signs. However, the participants have inadequate knowledge for the second stage, which are, the culture to create the connotative understanding in correct interpretation, respectively.

\section{Parable 2: Seperti kera mendapat bunga/Seperti monyet mendapat bunga}

'Seperti kera mendapat bungal Seperti monyet mendapat bunga' (Just as a monkey being given a flower) is to mean a person receiving something which is virtually useless. The situation was observed by the ancient society and it is based on nature, where the colourful flowers have attracted the attention of the monkeys. However, the flower cannot be used for anything much by the monkeys as flowers are their food. So, this means that the flowers will be damaged. Although the original habitat of apes and monkeys is in the wild, unfortunately the physical changes in the environment have caused the apes and monkeys to live in human residential areas. This is supported by [24], where the habitat-losing wildlife continues to roam and search for food in other places such as in agricultural farms and human settlements. A sharp observation of the behaviour of monkeys shows that they are often present in the housing areas/ villages and the presence of flowers of various shapes and colours often attracts them, thus sparking the idea behind this parable. The meaning of this parable connotatively in real life shows that there are people who do not appreciate something because they cannot/do not know how to use it. The human act of wasting the goods is reprimanded through the character of apes or monkeys to avoid in bringing the disgrace to the perpetrator. This was supported by [25], namely as the Malays used the proverb that supports the role of reprimand, sarcasm, teaching, giving opinions and expressing feelings about something.
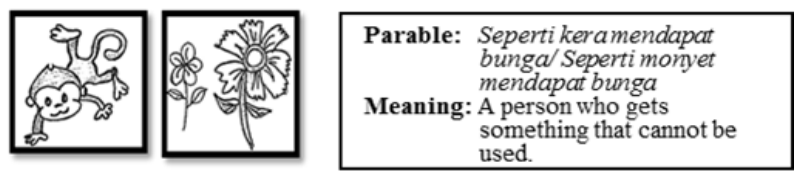

Answered by Study Participants (PK):

PK 1: Parable: Bagai monyet mencari makanan Meaning: Seorang yang suka merantau.

PK 2: Parable: Bagai monyet mencari bunga

Meaning: Orang yang mencari sesuatu tanpa putus asa.

PK 3: Parable: Bagai monyet dengan bunga

Meaning: Monyet disukai bunga.

PK 4: Parable: Seperti monyet mengandungi bunga matahari

Meaning: Monyet nampak sesuatu yang berwarna kuning iaitu matahari mengharumi monyet.

PK 5: Parable: Monyet memetik bunga yang cantik Meaning: Monyet mahu memetik bunga yang cantik itu.

All the participants were named the first object of the matching visual object as 'monyet' without anyone naming the object as kera, in this parable. This has prompted the researchers to refer to the Kamus dan Terjemahan Ringkas (Bahasa Temiar-Bahasa Melayu) by [26] and it has been discovered that there is no word 'kera' in this dictionary. The existing word is 'monyet'. Thus, these findings are in line with the Social Constructivism Theory which speaks of students' existing knowledge the five participants of this study, where their existing knowledge in the process of naming the first visual object in this parable is used. However, the complete answer to state the correct parable is still wrong and the study participants also failed to interpret the understanding of its meaning. However, PK 1 and PK 2 have begun to try to enter the second stage in the Semiotic Theory, where the culture of stating the meaning of this parable is connotative, even though the meaning is wrong. This means that the participants need to be exposed to the secondary stage, which involves theoretical notion, in order to be able to interpret the implied meaning accurately. Students need to be given more exposure to solve problems in order to reach a new level of cognitive production. According to [27], students who are able to control cognitive processes will succeed in solving 
problems.

\section{Parable 3: Bagai ayam disambar helang}

'Bagai ayam disambar helang' is to mean a person suddenly disappearing without news. The situation is seen externally- it shows the presence of eagles with the intention of grabbing/snatching the chicken very quickly and suddenly, and the chickens are not ready to defend themselves or seek refuge. The agility of an eagle, which is a kind of predatory animal or maging (carnivorous) is high. This is supported by [28], where the eagle is portrayed as an animal that is known to disturb livestock and ambush/attack (silent killer), by approaching the victim without the latter realizing it. An eagle's main food is small mammals such as rats, squirrels and chickens. The parable of 'bagai ayam disambar helang' arose based on the observations of the ancient society on the nature of an eagle. This sharp observation has established the proverb which proposes sarcasm/teasing, advise and allegory and Malay teaching values to all readers or listeners, [29]. The true meaning of this parable is related to the person who suddenly disappears without news. According to logical reasoning, when a person disappears suddenly, the situation occurring is swift, unnoticed by others and when it comes to light, is considered to be too late. Thus, this situation is illustrated by the agility of an eagle in getting its prey.

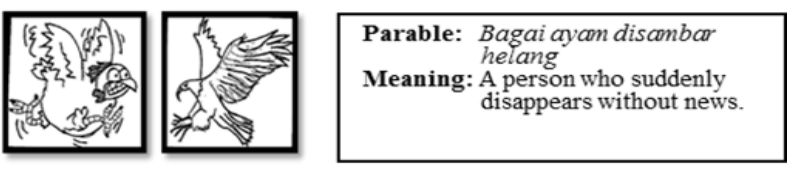

Answered by Study Participants (PK):

PK 1: Parable: Bagai duri dalam daging Meaning: Orang yang suka meninggi diri.

PK 2: Parable: Seperti ayam takut dengan helang Meaning: Orang yang penakut.

PK 3: Parable: Bagai helang dengan ayam Meaning: Helang sering berkejar dengan ayam.

PK 4: Parable: Seperti helang menangkap ayam Meaning: Helang sedang menangkap ayam, ayam berusaha berlari.

PK 5: Parable: Bagaikan ayam dengan burung helang Meaning: Burung helang menangkap ayam untuk dimakan.

PK 1, PK 3 and PK 4 had mistakenly named the visual object in the first visual object match for this parable. They have stated the visual object as 'duri' (PK 1) and 'helang' (PK 3 and PK 4), while the real picture is 'ayam' Meanwhile, though PK 2 and PK 5 correctly identified the first visual object as 'ayam', they were, however, still unable to write the correct parable. All student participants could not use the word 'disambar' which is a word that describes the agility of an eagle to get a chicken using its claws while flying. Since none of the participants were able to write the words 'disambar', the researchers think that the study participants' vocabulary is still limited and this poses as a problem to the participants if they are not aided by the visual images, as the Malay language is their B2. The same things were explained through [30] findings, where the learning of the Malay language as B2 is not an easy process, especially for the students who rarely use the Malay language as their mother-tongue while speaking. Less favourable environment and conditions have caused difficulty for the students to master the Malay language and in turn, this affects the performance of their learning process in the classroom. Clear evidence has been obtained from [15] findings, where most of the Orang Asli students have problems in mastering the 3M skills, namely reading (Membaca), writing (Menulis) and counting (Mengira). Although some students can read, not all of them, unfortunately, can understand the meaning of the full sentences. Based on the findings from parable 3 , the researchers found the various types of answers clearly show that the participants have not mastered the 'bagai ayam disambar helang' parable. So, the effect from this is that they also failed to give the meaning of this parable correctly.

Based on the findings of this study, the researchers found that all PKs from Orang Asli of the Temiar Tribe students do not have any problems to give a name for each matching visual object. All PKs can use the Malay language correctly without using any words from the Temiar language. This is in line with [31], where students use language functionality to communicate with each other, embody ideas and prove understanding of a content. However, all PKs face trouble in writing proverbs and parables in complete sentences, as well as giving answers to the meaning of all the questions on parables. Three question were asked and they were answered by all five PKs. If calculated, the total number of answers which require the participants to state the parables is 15 ; and the number of questions requiring the meaning is also 15 . However, the final results found that there was only one correct answer out of 15 answers from the parable questions, and no correct answers given for the questions on the meaning of parables. This shows that the mastery of the proverbial type of proverbs is still weak and has to be given in special and continuous attention.

\section{Conclusions}

From this study, it is clear that the mastery of parable meaning in Malay proverbs by the Orang Asli of the Temiar Tribe students, is still low. This matter should be addressed by all Malay language teachers so that this problem can be solved as the proverb is one of the components in the Malay language subject. Teachers need to act immediately to meet the needs of students. This is supported by [32], where teachers have the opportunity to 
diversify existing teaching methods with the help of technology. More accurate approaches and efforts need to be implemented so that the Orang Asli of the Temiar Tribe students can dominate the understanding of the parable meaning and Malay proverbs as well. The uniqueness of Malaysia as a country with different colours and races should not be a major barrier for a non-native speaker student to master and dominate the parables as well as Malay proverbs, and subsequently use the Malay language as the national language for the sake of unity. [33] found that there are two types of symbolism elements in Malay proverbs, which are the positive connotations (positive symbolism) and negative connotations (negative symbolism) to the tools, animals, plants and people or title. Thus, the parables which the Orang Asli of the Temiar Tribe students in this study were tested on are categorized as the negative connotations object. However, the parables listed in this study are matching visual objects that are relatively close to the participants' natural living environment. This matter is in line with [34] which states that the Malay proverbs use the symbol from nature and environment as in order to give the precise meanings based on the experience, observation and also sharp insights.

\section{Acknowledgements}

I would like to express my appreciation to my Supervisor, Dr. Wan Muna Ruzanna binti Wan Mohammad for the guidance given, the KPM Scholarship and Financing Division for sponsoring me by giving the Hadiah Latihan Persekutuan (HLP) and my family for all forms of support given. Thank you.

\section{REFERENCES}

[1] Undang-Undang Malaysia, Akta Pendidikan 1996 (Akta 550). Kuala Lumpur Percetakan Nasional Berhad, 1996.

[2] A. H. Omar, Kaedah penyelidikan bahasa di lapangan. Kuala Lumpur: Dewan Bahasa dan Pustaka, 2008.

[3] K. H. Kamarudin, and I. Ngah, Komuniti mapan: penilaian tahap kemapanan komuniti Orang Asli Temiar di negeri Perak. Journal of the Malaysian Institute of Planners, vol. 5, pp. $113-129,2007$.

[4] S. Mee, and Y. Ibrahim. Pembandaran dan penempatan semula komuniti Orang Asli. dalam Yahaya Ibrahim (Ed.), Komuniti Pembangunan \& Transformasi, pp. 203. Bangi: Universiti Kebangsaan Malaysia, 2009.

[5] JAKOA. Kenali Orang Asli Adat Istiadat dan Asal Usul. Online available from http://www.jakoa.gov.my/ wp-content/ uploads/2014/12/ kenali_orang_asli.pdf, 2014.

[6] I. Carey, Orang Asli: the aboriginal of Penisular Malaysia.

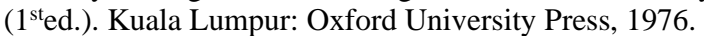

[7] Za'ba. Ilmu Mengarang Melayu. Kuala Lumpur: Dewan Bahasa dan Pustaka, 1965.

[8] K. B. Boon. Peribahasa Melayu dan peribahasa Cina satu perbandingan ringkas. Kuala Lumpur: Dewan Bahasa dan Pustaka, 1992.

[9] A. Mohd., and A. Hassan, Kamus pepatah, bidalan dan perumpamaan: (Edisi Kedua). Selangor: PTS Profesional, 2010.

[10] Z. A. Z. Hamzah, and A. F. M. Hassan. Peribahasa bahasa Melayu penelitian makna \& nilai. Serdang, Selangor: Penerbit Universiti Putra Malaysia, 2011.

[11] A. Yusof, A. M. Yatim, and M. R. Shaari, Semantik dan pragmatik bahasa Melayu. Kuala Lumpur: Pustaka Salam Sdn. Bhd., 2009.

[12] Z. Abdol. Peribahasa WATAFA, wajib tahu dan faham. Selangor Darul Ehsan: Penerbitan Pelangi Sdn. Bhd., 2018.

[13] N. Zila, Bahasa antara dalam pembelajaran bahasa Melayu sebagai bahasa kedua. Serdang, Selangor: Universiti Putra Malaysia, 2015.

[14] P. M. Lightbown, and N. Spada, How Languages are Learned ( $3^{\text {rd }}$ Ed.). New York: Oxford, 2006.

[15] A. S. Shaari, N. Yusoff, M. I. Gahzali, and M. H. Dali, Kanak-kanak minoriti orang asli di Malaysia: menggapai literasi bahasa Melayu, Jurnal Pendidikan Bahasa Melayu, vol. 1(2), pp. 59-70, 2011.

[16] C. F. Peng, Masalah pembelajaran bahasa Melayu dalam kalangan murid Cina sekolah rendah, Jurnal Pendidikan Bahasa Melayu -JPBM, vol. 6(2), pp. 10-22, 2016.

[17] R. Barthes, Teori Semiotik, Online available from http://visualmemory.co.uk/daniel/Documents/ S4B/sem06.html, 1987.

[18] L. Vygotsky. Teori Konstruktivisme Sosial. Online available from https:// www. slideshare. net / artyschatz / teori-konstruktivisme-oleh- vygotsky.

[19] Y. Kusumarini, Analisis teks dan kode interior gereja karya Tadao Ando "church of the light" dan "church on the water". Dimensi Interior, vol. 4(1), pp. 38-48, 2006.

[20] Ministry of Education Malaysia, Dokumen Standard Kurikulum dan Pentaksiran (DSKP) Bahasa Melayu Tingkatan Dua KSSM, Putrajaya: Bahagian Pembangunan Kurikulum, 2016.

[21] A. A. Rahman, Peribahasa sekolah menengah. Kuala Lumpur: Dewan Bahasa dan Pustaka, 2018.

[22] J. Nopiah, N. H. Jalaluddin, and J. Kasdan, Makanan 'berangin' dan 'berbisa' dalam peribahasa Melayu: analisis semantik inkusitif. International Journal of the Malay World and Civilisation, vol. 6(1), pp. 27-40, 2018.

[23] JAKOA. Portal Rasmi Jabatan Kemajuan Orang Asli Perak/Kedah, Online available from https://www.perakgis. my/jakoa/index.php/kenali-orang-asli/suku-kaum-orang-asli / kaum-temiar, 2019.

[24] S. H. Saaban, P. Sulai, I. Rasdi, and M. R. Zanudin, Manual pengurusan konflik manusia-kera di Semenanjung Malaysia. Jabatan Perlindungan Hidupan Liar dan Taman Negara. 
Kuala Lumpur: Percetakan Nasional Malaysia Berhad, 2006.

[25] A. Mohamed, and \& N. H. Jalaluddin, Abstraksi objek konkrit dalam peribahasa Melayu: analisis semantik inkuisitif, Jurnal Bahasa, vol. 18(2), pp. 197-218, 2018.

[26] K. Hisyam, Kamus dan Terjemahan Ringkas (Bahasa Temiar-Bahasa Melayu), Online available from https://www.academia.edu/5770537/DICTIONARY_KAM US_BAHASA_TEMIAR_KE_BAHASA_MELAYU_Dera f_2014, 2014.

[27] Masduki, M. N. Kholid, and R. P. Khotimah, Exploring students' problem-solving ability and response towards metacognitive strategy in mathematics learning, Universal Journal of Educational Research, vol. 8(8), pp. 3698-3703, 2020 .

[28] M. R. Saamah, Alam dan budaya dalam bahasa kiasan bahasa Semai, Seminar Penyelidikan 2011 Zon Timur, 2011.

[29] H. Baba, and N. H. Jalaluddin, Nilai Melayu dalam simpulan bahasa: analisis pragmatik, Seminar Linguistik Kebangsaan (SLiK2015), "Pelestarian dan Bahasa”, 2015.
[30] D. S. Ujai, and W. M. R. W. Mohammad, Pengaruh faktor sosial dalam pembelajaran bahasa Melayu dalam kalangan murid Iban, Jurnal Pendidikan Bahasa Melayu - JPBM, vol. 7(1), pp. 74-84, 2017.

[31] P. T. Adil, P. H. Policarpio, and C. F. Pamintuan, A communicative analysis of language functions in the Chinese as a Foreign Language (CFL) textbooks: the case of Happy Chinese. Universal Journal of Educational Research, vol. 8(8), pp. 3725-3733, 2020.

[32] J. Sulaiman, and S. N. Ismail, Teacher competence and $21^{\text {st }}$ century skills in transformation schools 2025 (TS25). Universal Journal of Educational Research, vol. 8(8), pp. 3536-3544, 2020.

[33] R. Rashidin, and N. Daud, Unsur perlambangan dalam bahasa Melayu: satu analisis teori relevans. Jurnal Aswara. Online available from www.aswara.edu.my/c/document_lib rary/get_file? uuid=c538310d, 2011.

[34] I. Ramly, Perkembangan peribahasa dalam bahasa Melayu, Jurnal Dewan Bahasa. vol. 34(1), pp. 54-61, 1990. 